\title{
Seleenin merkitys kasvintuotannossa
}

\author{
Marja Turakainen ${ }^{1)}$, Mervi Seppänen ${ }^{1)}$ ja Helinä Hartikainen ${ }^{2)}$ \\ 1) Soveltavan biologian laitos, PL 27,00014 Helsingin yliopisto, marja.turakainen@helsinki.fi \\ 1) Soveltavan biologian laitos, PL 27,00014 Helsingin yliopisto, mervi.seppanen@ helsinki.fi \\ 2) Soveltavan kemian ja mikrobiologian laitos, PL 27, 00014 Helsingin yliopisto, \\ helina.hartikainen@helsinki.fi
}

\section{Tiivistelmä}

Tutkijat totesivat 1950-ja 1960-luvulla seleenin (Se) puutteen olevan perimmäinen syy useisiin eläinten aineenvaihduntasairauksiin, joihin ei oltu keksitty siihen mennessä mitään hoitoa. Myöhemmin osoitettiin, että maataloustuotteiden alhaisella Se-pitoisuudella on negatiivisia vaikutuksia myös ihmisten terveyteen, sillä se vähentää solujen kykyä puolustautua happiradikaalien haitallisilta vaikutuksilta. Alhaisen Se:n saannin on arveltu lisäävän sydän- ja verisuonisairauksien ja syövän riskiä. Koska Suomen maaperässä on niukasti biologisesti käyttökelpoista Se:ä, sitä on vuodesta 1985 lisätty lannoitteisiin kansanterveydellisistä syistä. Vallinneen käsityksen mukaan kasvit eivät tarvitse Se:ä, vaikka kierrättävät sitä maasta eläimiin ja ihmisiin. Helsingin yliopistossa tehdyissä pitkäaikaisissa kokeissa on kuitenkin havaittu, että Se-lannoituksella on positiivisia vaikutuksia myös kasvien kasvuun ja niiden sadon laatuun.

Raiheinällä ja salaatilla tehdyissä kokeissa pieni Se-lisä edisti kasvien kasvua. Tulos selittyi mm. parantuneella antioksidatiivisten entsyymien tuotolla. Positiivinen vaikutus näkyi myös E-vitamiinin pitoisuuksissa, mikä osoitti Se-lannoituksen parantaneen myös kasvien ravitsemuksellista arvoa. Toisaalta lisäyksen ollessa suuri havaittiin kasveissa vakavia myrkytysvaikutuksia. Salaatilla tehdyissä kokeissa Se hidasti kasvin vanhenemista. Myöhemmissä kokeissa tehtiin mielenkiintoinen havainto, että lyhytaikainen UV-B -valokäsittely kasvihuoneessa alensi salaatin satoa, mutta yhdessä Se-lisän kanssa vaikutti kasvuun positiivisesti. Kun sopivan Se-annoksen havaittiin lisäävän tärkkelysjyvästen kertymistä salaatin lehtiin, tutkimuskasviksi otettiin runsaasti tärkkelystä keräävä kasvi, peruna. Niissä Se nopeutti kasvin palautumista hallasta sekä edisti tärkkelyksen ja sokereiden kertymistä perunan nuoriin lehtiin, kasvun myöhemmässä vaiheessa myös rönsyihin. Lisäksi Se:n huomattiin vaikuttavan positiivisesti sadonmuodostukseen, sillä Se-lannoitetut kasvit tuottivat suuremman sadon ja sekä vähemmän että keskikooltaan suurempia perunoita. Varastoinnin aikana ei tapahtunut muutoksia mukuloiden Se-pitoisuudessa. Se-lannoitus vaikutti edullisesti myös perunan sisäiseen laatuun. Raakatummuminen, joka on etenkin perunatuotteita valmistavan teollisuuden ongelma, väheni Se:ä saaneissa koejäsenissä. Hyvin korkea Se-lisä vähensi myös varhaisperunan glykoalkaloideja, jotka ovat perunan mukuloille tyypillisiä luonnollisia aineenvaihduntatuotteita.

Tulosten perusteella voidaan päätellä, että optimaalisena annoksena Se toimii kasveissa vastaavalla tavalla kuin eläin- ja ihmissoluissa eli puolustaa soluja happiradikaalien aiheuttamia hapettumisvaurioita vastaan. Seleeni hidastaa kasvien vanhenemista ja lisää kasvien stressinkestävyyttä tehostamalla kasvien antioksidatiivista puolustusjärjestelmää. Aikaisempien tutkimusten perusteella Se:ä ei luokitella kasveille välttämättömäksi hivenravinteeksi. Pitkäaikaisista Helsingin yliopistossa tehdyistä tutkimuksista saadut tulokset ovat kuitenkin vahvistaneet käsitystä siitä, että Se on kasveille erittäin tarpeellinen alkuaine.

Avainsanat: seleeni, salaatti, raiheinä, peruna, apila, antioksidantit, stressinkestävyys, sato, tärkkelys, varastointilaatu, glykoalkaloidit 


\section{Johdanto}

Pitkään vallinneen käsityksen mukaan kasvit eivät tarvitse seleeniä (Se), vaikka ne ovatkin keskeisessä asemassa sen kierrätyksessä maasta ihmiseen - suoraan tai eläinten välityksellä. Pitkäaikaiset Helsingin yliopistossa tehdyt kokeet ovat kuitenkin antaneet aihetta olettaa, että Se:llä on suurempi merkitys kasveille kuin on uskottu. Kokeet ovat perustuneet oletukseen, että samalla tavalla kuin ihmisissä ja eläimissä Se pystyy sopivalla pitoisuustasolla toimimaan myös kasveissa hapettumisvaurioilta suojaavana tekijänä. Hapettumisstressiä aiheuttavia happiradikaaleja syntyy kasvin normaalien elintoimintojen kuten yhteyttämisen ja hengityksen yhteydessä sekä ulkoisten stressitekijöiden kuten lyhytaaltoisen valon, kylmyyden tai hallan synnyttäminä. Kokeita on tehty useiden vuosien aikana sekä rehu- että ravintokasveilla. Niissä on seurattu nousevien Se-lisäysten vaikutuksia $\mathrm{mm}$. kasvien Se-pitoisuuksiin ja satoon, solujen hapettumisvaurioihin, antioksidatiivisten entsyymien aktiivisuuteen, E-vitamiinipitoisuuteen, tärkkelyksen ja sokereiden kertymiseen ja joihinkin muihin sadon laatua indikoiviin ominaisuuksiin.

\section{Aineisto ja menetelmät}

\section{Koejärjestelyt}

Kokeita tehtiin sekä kasvihuoneessa että kasvatuskaapissa. Koekasveina oli salaatti (Lactuca sativa), raiheinä (Lolium perenne), puna-apila (Trifolium pratense) ja peruna (Solanum tuberosum L.). Kasvualustana käytettiin aluksi maata, jota ei oltu koskaan lannoitetu Se:llä. Myöhemmissä kokeissa, joissa haluttiin selvittää tarkemmin Se:n vaikutusta kasvissa ja siksi varmentaa kasvien Se:n saanti, käytettiin inerttinä kasvualustana vermikuliittia tai kvartsihiekkaa. Raiheinä- ja salaattikokeissa Selannoitus annettiin nousevina pitoisuuksina suoraan maahan seleenihappona $\left(\mathrm{H}_{2} \mathrm{SeO}_{4}\right)$ tai natrium selenaattina $\left(\mathrm{Na}_{2} \mathrm{SeO}_{4}\right)$, perunakokeissa kastelun yhteydessä. Kontrollikasvit kasteltiin vedellä.

Perunan hallanaltistuskokeet tehtiin kasvatuskaapissa kuten kuvailtu Seppänen ym. (2003). Kasveista määritettiin lehtivihreäpitoisuus $0,2,6$ ja 8 tunnin kuluttua altistuksesta Lichtenthalerin (1987) mukaan. Viherhiukkasten hajoamista käytetään tutkimuksissa kuvaamaan kasvien yhteyttämistehokkuutta ja stressinsietokykyä.

Kaikista sadoista punnittiin tuorepainot ja määritettiin kuivapainot. Perunakokeissa sato korjattiin 16 viikon kuluttua istutuksesta. Kokonaisperunasato ja perunoiden paino punnittiin ja lukumäärä astiaa kohti laskettiin. Lisäksi perunoiden liukoisten sokerien ja tärkkelyksen pitoisuus määritettiin. Lehtien tärkkelyspitoisuus määritettiin 4 viikon ja rönsyjen 8 viikon kuluttua istutuksesta. Noston jälkeen perunat varastoitiin $4{ }^{\circ} \mathrm{C}$ :ssa $75 \%$ :n kosteudessa. Yhden ja kahdeksan kuukauden varastoinnin jälkeen perunoista tehtiin raakatummumismääritys. Perunat halkaistiin ja tummuneiden perunoiden osuus (\%) ja niiden tummumisen aste määritettiin aistinvaraisesti 30 ja 60 min kuluttua Perunantutkimuslaitoksen ohjeiden mukaisesti. Seleenin säilymistä perunoissa varastoinnin aikana tutkittiin määrittämällä niiden Se-pitoisuus 1, 6 ja 12 kuukauden varastoinnin jälkeen. Seleenin kuljetusta siemenperunasta seuraavan vuoden perunasatoon tutkittiin astiakokeessa, jossa Selannoituksen saaneet siemenperunat istutettiin kasvihuoneelle ja niistä korjatusta perunasadosta määritettiin Se-pitoisuus.

\section{Analyysimenetelmät}

Kasvien Se-pitoisuus määritettiin pakastekuivatusta ja jauhetusta kasvimateriaalista atomiabsorptiospektofotometrillä Kumpulaisen ym. (1983) ja Ekholmin (1997) kuvaamalla menetelmällä. Lipidien hapettuminen määritettiin mittaamalla tiobarbituurihappo-reaktiiviset aineet (TBARS) muunnellulla Yagin (1982) menetelmällä. Antioksidatiivisen GSH-Px-entsyymin (EC1.11.1.9) aktiivisuuden määritys tehtiin Flohen and Gunzlerin menetelmän muunnoksella (tarkemmin Hartikainen ym. 2000). $\alpha$ - and $\gamma$-tokoferolit (E-vitamiini) analysoitiin Xuen ym. (1997) kehittämällä mikromittakaavan HPLC-menetelmällä. Tärkkelyspitoisuuden määrittämisessä käytettiin Palosen (1999) kuvaamaa menetelmää, ja liukoisten sokerien määrityksessä anthron-menetelmää (Yemm ja Willis 1954). 


\section{Tulokset ja tulosten tarkastelu}

\section{Seleenilisäyksen vaikutus kasvuun}

Ensimmäisen hietamaalla tehdyt astiakokeen tulokset osoittivat, että sopivan alhainen Se-lannoitus (8-33 $\mu \mathrm{g} / \mathrm{kg}$ maata) lisäsi salaatin ja raiheinän kasvua normaaleissa kasvuoloissa. Koe antoi myös viitteitä antioksidatiivisen kapasiteetin lisääntymisestä kasveissa (Hartikainen ym. 1997). Havainnot saivat tukea myöhemmistä kokeista, joissa sopivina määrinä annettu Se-lannoitus paransi salaatin kasvua ja lisäsi sen antioksidatiivisten entsyymien aktiivisuutta (Hartikainen ja Xue 1999, Xue ja Hartikainen 2000). Kokeessa, jossa seurattiin salaatin kasvua viikon välein tehdyin mittauksin, Se:ä $(0.05 \mathrm{mg} / \mathrm{kg})$ saaneiden kasvien biomassa oli 7 viikon ajan suurempi kuin kontrollikasvien (Pennanen ym. 2002). Korkea Se-lisäys (yli $10 \mathrm{mg} / \mathrm{kg}$ maata) osoittautui kokeissa toksiseksi, se alensi merkittävästi kasvua (Hartikainen ym. 2000). Haitallinen vaikutus oli yhteydessä solujen hapettumisvaurioiden lisääntymiseen, mikä osoitti Se-ylimäärän toimineen kasvissa pro-oksidanttina. Seleeni on kemiallisilta ominaisuuksiltaan rikin kaltainen. Se korvaa rikin aminohapoissa, jolloin proteiinien rakenne ja entsyymien toiminta muuttuu. Kasvit kykenevät puolustautumaan Se:n ylimäärä vastaan muuttamalla Se:n dimetyyliselenidiksi, joka haihdutetaan lehtien ja juurten kautta (PilonSmith ym. 1998; Terry ym. 2000). Tämä ilmiö tuli esiin myös Hartikaisen ym. (2000) tekemässä kokeessa.

\section{Seleenin vaikutus kasvien stressinsietoon}

Kasvit tarvitsevat puolustusmekanismeja suojautuakseen sisäisten tai ulkoisten stressitekijöiden aiheuttamilta solujen hapetusvaurioilta. Vanheneminen on luonnollinen kasvien kehitysvaihe, jolloin solujen lipidien hapettuminen lisääntyy. Seleenin vaikutusta kasvien vanhenemiseen selvitettiin kokeessa, jossa ensimmäinen salaattierä korjattiin sopivassa myynti-iässä 49 päivää vanhana, toisen erän annettiin kasvaa 96 päivää. Siinä havaittiin, että sopiva Se-lisä $(0.1 \mathrm{mg} / \mathrm{kg})$ hidasti kasvien vanhenemista ja E-vitamiinipitoisuuden vähenemistä kasvin ikääntyessä (Xue ym. 2001). Tulos osoitti, että Se:ä saaneet kasvit säilyttivät pidempään tuoreutensa ja ravintoarvonsa. Seleenin kykyä puolustaa kasvia ulkoisten stressitekijöiden haittavaikutuksia vastaan selvitettiin kasvihuoneoloissa altistamalla kasveja lyhyille UV(B)-säteilykäsittelyille. Korkeaenerginen UV(B)-säteily heikensi selvästi salaatin kasvua, mutta ei vaikuttanut raiheinän kasvuun. Mielenkiintoista oli, että yhdessä Se:n kanssa UV(B)-säteily edisti sekä raiheinän että salaatin kasvua (Hartikainen ja Xue 1999).

Seleenin ja korkeaenergisen valon positiivinen synergistinen vaikutus kasvuun perustunee hapetusvaurioiden vähenemiseen, yhteyttämiseen osallistuvien entsyymien suojaamiseen ja valon tehostuneeseen hyväksikäyttöön (Pennanen ym. 2002). Seleenin positiivinen vaikutus havaittiin myös solutasolla. Nuorista salaatinlehdistä otetut elektronimikroskooppikuvat osoittivat, että tärkkelystä kertyi enemmän Se:ä saaneiden kasvien viherhiukkasiin (Pennanen ym. 2002). Tämä oli mielenkiintoinen havainto, jonka seuraaviin kokeisiin valittiin koekasviksi runsaasti tärkkelystä keräävä kasvi, peruna.

\section{Seleenin vaikutus perunan sadon määrään ja laatuun}

Perunalla tehdyt kokeet vahvistivat käsitystä, että Se edistää tärkkelyksen kertymistä kasvissa. Seleeniä saaneen perunan lehtiin ja rönsyihin kertyi enemmän tärkkelystä kuin kontrollikasveihin (Turakainen ym. 2004a). Kvartsihiekassa kasvaneet Se-lisäyksen (0.075 ja $0.3 \mathrm{mg} / \mathrm{kg}$ ) saaneet kasvit tuottivat myös suuremman mukulasadon kuin ilman lisäystä jääneet. Korkeimmalla Se-lisäyksellä (0.3 $\mathrm{mg} / \mathrm{kg}$ ) perunoiden keskipaino oli suurempi kuin kontrollikasveilla, mutta niiden määrä kasvia kohti oli pienempi. Samalla havaittiin, että niihin oli kertynyt enemmän tärkkelystä, kun taas liukoisten sokereiden pitoisuus oli alentunut (Turakainen ym. 2004a). Tulokset osoittavat, että lehtiin kertyneitä tärkkelysvarastoja voidaan ainakin osittain siirtää perunaan.

Seuraavissa kokeissa selvitettiin Se-lannoituksen vaikutusta perunan sisäiseen laatuun 1 . glykoalkaloidien pitoisuuteen ja mukuloiden raakatummumiseen. Glykoalkaloidit ovat perunassa luonnollisesti esiintyviä, stressitekijöiden seurauksena syntyviä kasvin puolustusaineita, jotka ovat korkeina pitoisuuksina ihmisille haitallisia (Friedman ja Dao 1992, Papathanasiou ym. 1999). Se- 
lannoitus alensi tuleentumattomana nostetun varhaisperunan glykoalkalodipitoisuutta jonkin verran, mutta vasta Se-pitoisuudessa ( $20 \mu \mathrm{g} / \mathrm{g}$ perunan kuiva-ainetta), jota pidetään liian korkeana ravitsemuksellisessa mielessä (Turakainen ym. 2004b). Seleenin vaikutusmekanismia glykoalkaloidien alenemiseen ei tunneta, mutta se saattaa alentaa glykoalkaloidien muodostumiseen vaikuttavien entsyymien aktiivisuutta.

Perunoiden raakatummuminen johtuu fenolisten yhdisteiden entsymaattisesta hapettumisesta värillisiksi yhdisteiksi kuorinnan yhteydessä (Friedman 1997). Perunoiden käyttölaatua heikentävää raakatummumista selvitettiin varastointikokeessa, jossa seurattiin eri Se-määriä $(0,0.0035,0.01,0.075$ ja $0.9 \mathrm{mg} / \mathrm{kg}$ ) saaneitten perunoiden tummumisherkkyyttä sekä tummuneiden perunoiden osuutta koeerässä. Kuukauden varastoinnin jälkeen tehdyssä testissä havaittiin, että Se-lisäyksen saaneiden perunoiden raakatummuminen oli hitaampaa 60 min kuluttua halkaisusta kuin kontrolliperunoiden. Varastointiajan pidetessä kahdeksaan kuukauteen perunoiden raakatummisenkestävyys parani kaikilla koejäsenillä, mutta alhaisin Se-annos $(0.0035 \mathrm{mg} / \mathrm{kg})$ vähensi myös tummuneiden perunoiden osuutta. Seleenin positiivinen vaikutus perunan raakatummumisen kestävyyteen on yhteydessä Se:n antioksidatiivisiin ominaisuuksiin. On myös mahdollista, että Se alentaa raakatummumiseen osallistuvien entsyymien aktiivisuutta (Turakainen ym. käsikirj.).

Perunoiden Se-pitoisuudessa ei tapahtunut muutoksia varastoinnin aikana. Tuloksen perusteella perunan Se-pitoisuus ei alene aineenvaihdunnan seurauksena, joten Se:n antioksidatiiviset eli vanhenemista hidastavat ominaisuudet säilyvät koko varastointikauden ajan. Kun Se-lannoitusta saaneita perunoita käytettiin seuraavana vuonna siemenperunoina, niistä siirtyi Se:ä seuraavan vuoden mukuloihin (Turakainen ym. käsikirj.). Seuraavan sadon perunoiden Se-pitoisuudet olivat kuitenkin huomattavasti alhaisempia, sillä siemenperunan Se jakautui koko kasviin.

\section{Kasvien kylmänkestävyys ja seleeni}

Viljelty peruna on kylmänaltis kasvi. Alhainen lämpötila yhdessä korkean valon kanssa vaurioittaa kasvia ja alentaa sen yhteyttämiskykyä (Seppänen ym. 2001, Seppänen ja Coleman 2003). Hallanaltistuskokeen tulosten perustella, Se nopeutti perunan palautumista korkean valon ja alhaisen lämpötilan aiheuttamasta stressistä eli kasvien kyky kestää oksidatiivista stressiä parani (Seppänen ym. 2003).

Se-lisäys edisti puna-apilan vararavintovarastojen kertymistä. Seleenilannoitus $(0.2$ ja $2.0 \mathrm{mg} \mathrm{Se}$ astia $^{-1}$ ) lisäsi puna-apilan talvehtivien kasvinosien; tyven ja juurten tärkkelyspitoisuutta (Seppänen ym. käsikirj.).

\section{Johtopäätökset}

Optimaalisena annoksena Se toimii kasveissa vastaavalla tavalla kuin eläin- ja ihmissoluissa eli puolustaa soluja happiradikaalien aiheuttamia hapettumisvaurioita vastaan. Seleenin antioksidatiiviset vaikutukset hidastavat kasvien vanhenemista ja lisäävät kasvien stressinkestävyyttä tehostamalla kasvien puolustusjärjestelmää. Seleenillä on positiivinen vaikutus kasvien kasvuun sekä normaali kasvuoloissa että UV-stressissä sekä tärkkelyksen kertymiseen lehtiin ja mukuloihin ja juureen. Seleenillä on edullinen vaikutus perunan sisäiseen laatuun. Varastoinnin aikana perunan Sepitoisuudessa ei tapahdu muutoksia. Siemenperunan Se kuljetetaan seuraavaan perunasatoon. Kasvit toimivat eräänlaisina biologisina puskureina liian korkeaa Se vastaan, koska niiden kasvu pysähtyy Se-pitoisuuden noustessa lian korkeaksi.

Aikaisempien tutkimusten mukaan Se:ä ei luokitella kasveille välttämättömäksi hivenravinteeksi. Viimeaikaisista tutkimuksista saadut tulokset ovat kuitenkin vahvistaneet käsitystä siitä, että Se on kasveille erittäin tarpeellinen alkuaine.

\section{Kirjallisuus}

Ekholm, P. 1997. Effects of selenium supplemented commercial fertilizers on food selenium contents and selenium intake in Finland. EKT-series 1047. Helsinki. ISBN 952-90-8392-0 (dissertation). 
Flohe, L. \& Gunzler, W. A. 1984. Assays of glutathione peroxidase. Teoksessa; Methods in Enzymology. Volume 105. Toim. L. Packer. Academic Press. New York. s. 114-121.

Friedman, M. \& Dao, L. 1992. Distribution of glycoalkaloids in potato plants and commercial potato products. J. Agric. Food Chem. 40: 419-423.

Friedman, M. 1997. Chemistry, biochemistry, and dietary role of potato pholyphenols. A review. J. Agric. Food Chem. 45: 1523-1540.

Hartikainen, H., Ekholm, P., Piironen, V., Xue, T., Koivu, T. \& Yli-Halla, M. 1997. Quality of ryegrass and lettuce yields as affected by selenium fertilization. Agric. and Food Sci. Finland 6: 381-387.

Hartikainen, H. \& Xue, T. 1999. The promotive effect of selenium on plant growth as triggered by ultraviolet irradiation. J. Environ. Qual. 28: 1372-1375.

Hartikainen, H., Xue, T., \& Piironen, V. 2000. Selenium as anti-oxidant and pro-oxidant in ryegrass. Plant Soil 225: 193-200

Kumpulainen, J., Raittila, A-M, Lehto, J. \& Koivistoinen, P.1983. Electrothermal atomic absorption spectrometric determination of selenium in foods and diets. J. Assoc. Offic. Anal. Chem. 66: 1129-1135.

Lichtenthaler, H. H. 1987. Chlorophylls and carotenoids: pigments of photosynthetic biomembranes. Methods Enxymol. 148: 350-382.

Palonen P. 1999. Relationship of seasonal changes in carbohydrates and cold hardiness in canes and buds of three raspberry cultivars. J. Am. Soc. Hortic. Sci. 124: 507-513.

Papathanasiou, F.; Mitchell, S. H., Watson, S. \& Harvey, B. M. R. 1999. Effect of environmental stress during tuber development on accumulation of glycoalkaloids in potato (Solanum tuberosum L.). J. Sci. Food Agric. 79: 1183-1189.

Pennanen, A., Xue, T. \& Hartikainen, H. 2002. Protective role of selenium in plant subjected to severe UV irradiation stress. J. Appl. Bot. 76: 66-76

Pilon-Smith, E., de Souza, M., Lytle, C., Shang, C., Lugo, T. \& Terry, N. 1998. Selenium volatilization and assimilation by hybrid poplar (Populus tremulus x alba). J. Exp. Bot. 328: 1889-1892.

Seppänen, M. M. , Nissilä, O. \& Perälä, S. 2001. Agric. and Food Sci. Finland 10: 153-163.

Seppänen, M. M. \& Coleman, G. D. 2003. Characterization of genotypic variation in stress gene expression and photosynthetic parameters in potato. Plant Cell Environ. 26: 401-410.

Seppänen, M., Turakainen M. \& Hartikainen, H. 2003. Selenium effects on oxidative stress in potato. Plant Sci. 165: 311-319.

Terry, N. \& Zayed, A.M. 1998. Phytoremediation of selenium. In: Frankenberger WT Jr, and Engberg RA (Eds) Environmental chemistry of selenium. Marcel Dekker Inc, New York, pp. 633-655.

Terry, N., Zayed A. M., de Souza M. P. \& Tarun, A. S. 2000. Selenium in higher plants. Annu. Rev. Plant Physiol. Plant Mol. Biol. 51: 401-432.

Turakainen, M., Hartikainen, H. \& Seppänen, M. M. 2004a. Effects of selenium treatments on potato (Solanum tuberosum L.) growth and concentrations of soluble sugars and starch. Agric. Food Chem. 52: 53785382 .

Turakainen, M., Väänänen, T., Anttila, K., Ollilainen, V, Hartikainen, H. \& Seppänen, M. M. $2004 b$. Effect of selenate supplementation on glycoalkaloid content of potato (Solanum tuberosum L.). J. Agric. Food Chem. 52: 7139-7143.

Xue. T., Piironen, V. \& Hartikainen, H. 1997. A small scale HPLC method for the determination of $\alpha$ tocopherol in fresh plant tissues. Agribiol. Res. 50: 265-270.

Xue, T. \& Hartikainen, H. 2000. Association of antioxidative enzymes with the synergistic effect of selenium and UV irradiation enhancing plant growth. Agric. Food Sci. Finland 9: 177-186.

Xue T., Hartikainen, H. and Piironen, V. 2001. Antioxidative and growth-promoting effect of selenium on sensecing lettuce. Plant Soil 237: 55-61.

Yagi, K. 1982. Lipid peroxides in biology and medicine. Academic Press, New York. s. 223-230. 
SUOMEN MAATALOUSTIETEELLISEN SEURAN TIEDOTE NRO 21

Yemm, E. W. \& Willis, A. J. 1954. The estimation of carbohydrates in plant extracts by anthrone. Biochem. J. 57: 508-514. 